\title{
Romatoid Artritli Hastaların Perspektifinden Yaşam Deneyimleri: Fenomenolojik Bir Yaklaşım
}

\author{
(iD) Sibel Şentürk ${ }^{1}$ (iD) Gezmiş Kimyon ${ }^{2}$ \\ ${ }^{1}$ Dr. Öğr. Üyesi, Burdur Mehmet Akif Ersoy Üniversitesi Bucak Sağıık Yüksekokulu, İç Hastalıkları Hemşireliği Anabilim Dalı, \\ Burdur, Türkiye. \\ ${ }^{2}$ Dr. Öğr. Üyesi, Hatay Mustafa Kemal Üniversitesi Tayfur Ata Sökmen Tıp Fakültesi, Romatoloji Anabilim Dalı, Hatay, Türkiye. \\ $\ddot{0} z$
}

Romatoid Artritli Hastaların Perspektifinden Yașam Deneyimleri: Fenomenolojik Bir Yaklașım

Amaç: Araștırmanın amacı, romatoid artritli hastaların perspektifinden yaşam deneyimlerinin derinlemesine aktarılmasıdır.

Gereç ve Yöntem: Tanımlayıcı ve fenomenolojik olarak tasarlanan bu araștırma, 15 Temmuz- 15 Ağustos 2020 tarihleri arasında romatoloji polikliniğine muayene olmak için gelen ve en az 1 yıldır romatoid artrit tanısı olan toplam 24 birey ile tamamlanmıştır. Veriler, araştırmacılar tarafından olușturulan "Hasta Tanıım Formu” ve "Yarı Yapılandırılmış Görüșme Formu” ile yüz yüze görüșülerek toplanmıștır. Görüșmeler sırasında romatoid artritli hastaların ifadeleri ses kayıt cihazı ile kaydedilmiștir. Verilerin değerlendirilmesinde içerik analizi yöntemi kullanılmıştır.

Bulgular: Yapılan kodlamalar sonucunda 3 tema belirlenmiștir. 1) Tanıya verilen ilk tepki, 2) Romatoid artrit semptomlarının hastalar üzerindeki etkisi, 3) Baș etme stratejileri. Romatoid artritli hastaların bir kısmı ilk tanı konulduğunda inkâr ve öfke yașarken bir kısmı da aile üyelerinde aynı hastalık bulunduğu için kabullenmiștir. Hastalıkla birlikte yaşamları fiziksel, duygusal, emosyonel, sosyal ve ekonomik açıdan etkilenmiștir. Hastalıkla bașa çıkarken tedaviye uyum sağlama, aile desteği alma, öz-yönetimlerini güçlendirme ve dine yönelme gibi yöntemleri kullandıkları belirlenmiștir.

Sonuç: Bu çalışma, romatoid artritin hastaların yaşamlarını tanı konduğu andan itibaren nasıl etkilediğini ve hastalıkla nasıl baş ettiklerini ortaya koymaktadır. Sağlık profesyonellerinin hastalık yönetiminde hastanın bakıș açısını dikkate alma ve holistik bir yaklașımla tedavilerini oluşturmaları önerilmektedir.

Anahtar Kelimeler: Romatoid Artrit, Yaşam Deneyimi, Fenomenolojik Yaklaşım

\section{Abstract}

Life Experiences from the Perspective of Patients with Rheumatoid Arthritis: A Phenomenological Approach

Objective: The aim of this research is to convey in-depth life experiences from the perspective of patients with rheumatoid arthritis.

Methods: This descriptive and phenomenological study was completed with a total of 24 individuals who came to the rheumatology outpatient clinic for examination between 15 July and 15 August 2020 and had rheumatoid arthritis for at least 1 year. The data were collected through face-to-face interviews with the "Patient Information Form" and "Semi-structured Interview Form" created by the researchers. During the interviews, the statements of the patients with rheumatoid arthritis were recorded with a voice recorder. Content analysis method was used in the evaluation of the data.

Results: As a result of the coding, 3 themes were determined. 1) Initial response to diagnosis, 2) Impact of rheumatoid arthritis symptoms on patients, 3) Coping strategies. While some of the patients with rheumatoid arthritis experienced denial and anger when the diagnosis was first made, some of them accepted because their family members had the same disease. With the disease, their lives have been affected physically, emotionally, socially and economically. It was determined that they used methods such as adapting to treatment, receiving family support, strengthening their self-management and turning to religion when coping with the disease.

Conclusion:This study reveals how rheumatoid arthritis affects patients' lives from the moment they are diagnosed and how they cope with the disease. It is recommended that health professionals consider the patient's point of view in disease management and create their treatment with a holistic approach.

Keywords: Rheumatoid Arthritis, Life Experience, Phenomenological Approach

Nasıl Atıf Yapmalı: Șentürk S, Kimyon G, .Romatoid Artritli Hastaların Perspektifinden Yașam Deneyimleri: Fenomenolojik Bir Yaklașım MKÜ Tıp Dergisi. 2021;12(44):219-225. https://doi.org/10.17944/mkutfd.974629

Sorumlu Yazar/Corresponding Author: Dr. Öğr. Üyesi Gezmiş Kimyon

Email: gkimyon@gmail.com

Geliș/Received: 26 Temmuz 2021

ORCID iD: 0000-0003-3775-639X 


\section{Giris}

Romatoid artrit (RA), etiyolojisi tam olarak bilinmeyen, eklemlerin iltihaplanmasına ve ağrılı șişmesine, hastalığın ilerlemesi ile birlikte kalıcı eklem hasarına ve fiziksel fonksiyon kayıplarına neden olan kronik, inflamatuar ve sistemik bir eklem hastalığıdır (1). Klinik olarak, erken evre RA, yorgunluk, halsizlik, șiş ve hassas eklemler, sabah tutukluğu gibi genel hastalık semptomları ile karakterizedir. Buna karșılık, yetersiz tedavi edilen ve ilerleyen dönemde RA, plevral efüzyonlar, interstisyel akciğer hastalığı, lenfomalar, vaskülit, keratokonjonktivit, ateroskleroz, hematolojik anormallikler, eklemlerde şekil bozukluğu, hareket açıklığı kaybı, kemik erozyonu ve romatizmal nodüller gibi sistemik belirtilerin görülmesine neden olmaktadır (2). Bu durumlar hastaların RA'nın yașam boyu etkileriyle yaşamak zorunda kalmasına, sakatlık durumIarının olușmasına, bașkalarına bağımlı hale gelmelerine ve mortalite artışına neden olmaktadır $(2,3)$.

Romatoid artritli bireyler yaşamları boyunca farklı şiddette ağrı, sertlik, gün içerisinde dinlenme ihtiyacının artması, șekil bozuklukları, fiziksel ișlev kaybı, çalıșma kabiliyetinde bozulma ve buna bağlı gelir kaybı, iş kayıpları, sağlık harcamalarında artış, boș zaman aktivitelerinde azalma, sosyal izolasyon, benlik saygısında azalma, depresyon, anksiyete ve aile içi ilișkilerde bozulma gibi fiziksel, psikolojik, sosyal ve ekonomik yönden problemlerle karșı karșıya kalmaktadırlar. Ağrılı seyir ve yașamın çeșitli alanlarındaki aktiviteleri gerçekleștirmedeki kısıtlamalar RA’lı hastaları tatmin edici bir yaşam sürmekten alıkoyarak yașam kalitelerini olumsuz etkilemekte ve hastalıkla baș etmelerini zorlaștırmaktadır (1,47). RA'lı hastaların yașadıkları bu problemler nedeniyle nicel veriler dışında nitel verilerle de sorgulanmaları ve multidisipliner bir tedavi yaklaşımı ortaya konulmalıdır. Bu nedenle, hastaların günlük yașamlarında hastalığın etkilerini nasıl deneyimledikleri ve hastalar için en iyi bakım uygulamalarına nasıl katılabilecekleri konusunda sağlık uzmanlarına değerli bilgiler sağlamak büyük önem tașımaktadır (8). Bu düșünceden hareketle bu çalıșmada, RA'lı hastaların tanıya yönelik tepkilerini, tanı alma sürecinden itibaren hayatlarındaki değișimleri, yașadıkları zorlukları ve baș etme yöntemlerini kendi perspektiflerinden aktarmayı amaçladık.

\section{GEREÇ VE YÖNTEM}

Araștırmanın Tipi

Araștırma, betimsel fenomenolojik nitel bir çalıșma olarak planlanmıștır.

\section{Araștırmanın Evren ve Örneklemi}

Araștırmanın evrenini 15 Temmuz- 15 Ağustos 2020 tarihleri arasında bir üniversitenin Sağıı Uygulama ve Araștırma Hastanesi romatoloji polikliniğine muayene olmak için gelen hastalar olușturmuștur. Örneklemi ise (a) en az 1 yıldır RA ta- nısı olan, (b) çalıșmanın yapıldı̆̆ı tarihlerde romatoloji polikliniğine muayene olmak için gelen, (c) American College of Radiology (ACR) ve/veya American College of Radiology-European League Against Rheumatism (ACR-EULAR) 2010 kriterlerine göre hekim tarafından RA tanısı konmuș, (d) iletişim ve algılama sorunu olmayan (e) Türkçe anlayabilen ve konuşabilen ve (f) çalıșmaya katılmayı kabul edip veri doygunluğuna ulaşılan toplam 24 RA'lı birey oluşturmuş̦tur.

\section{Veri Toplama Formu}

Veriler, araștırmacılar tarafından literatür taranarak hazırlanan RA'lı bireylerin sosyodemografik verilerinin olduğu "Hasta Tanıtım Formu" ve "Yarı Yapılandırılmış Görüșme Formu” ile toplanmıștır (4-7). Hasta Tanıtım Formunda, RA'ı bireylerle ilgili 9 soru (yaș, cinsiyet, medeni durum, eğitim durumu, mesleği, gelir düzeyi, yaşadığı yer, sigara ve alkol kullanma durumu) ve RA'lı hastaların hastalık özelliklerini içeren 8 soru (hastalık yılı, ailede RA hastalığı varlığı, deformasyon gelișme durumu, deformasyon gelișmiș ise anatomik olarak yeri, RA nedeniyle yaşadığı semptomlar, eşlik eden hastalıklar, ilaçlarını düzenli kullanma ve kontrollere düzenli gelme durumu, DAS-28 skoru) olmak üzere toplam 17 soru yer almaktadır. Yarı Yapılandırılmış Görüșme Formunda ise RA'ı hastaların yașam deneyimlerini belirlemek için yönlendirici olmayan, geneli kapsayan 4 adet açık uçlu soru yöneltilmiştir. Çalıșmada RA'ı hastalara yöneltilen açık uçlu sorular, 'HastaIığınız ilk teșhis edildiğinde ne düșündünüz? Neden? 'Romatoid artrit tanısı almak hayatınızı nasıl etkiledi?", 'Romatoid artritli bir hasta olarak yașadığınız zorluklar nelerdir?", "Bu zorluklarIa nasıl başa çıkıyorsunuz?” șeklinde sıralanmıștır.

\section{Verilerin Toplanması}

Veriler, araștırmaya katılmayı kabul eden hastalarla belirlenen tarih ve saatlerde yüz yüze görüșme yöntemi kullanılarak yarı yapılandırılmış soru formu aracılığıyla toplanmıștır. COVID-19 pandemi süreci nedeniyle görüșmeler maske, sosyal mesafe ve hijyen kurallarına uyularak yerine getirilmiştir. Görüșmelere bașlamadan önce araștırma protokolü anlatılmıştır. Görüșme sırasında RA'lı bireylerin ifadeleri ses kayıt cihazı ile kaydedilmiş ve gerekli yerlerde notlar alınmıştır. Görüșmeler ortalama 30-35 dakika arasında sürmüștür.

\section{Verilerin Analizi}

Verilerin analizinde nitel içerik analiz yöntemi kullanılmıştır. Yapılan tüm görüșmelerin ses kayıtları görüșme sonrasındaki 24 saat içerisinde manuel olarak deșifre edilmiștir. Her bir transkripsiyon ișlemi yaklașık 35-40 dakika sürmüștür. Araştırmacılar, daha sonra veriler üzerinde tartıșıp, en uygun olan temaları belirlemişlerdir. Çalıșmada, güvenirliği sağlamak amacıyla katılımcılardan kendi görüșme kayıtlarının yazıya aktarılmış hallerini okumaları ve görüșlerinin doğru olarak aktarıldığını onaylamaları istenerek katılımc teyidi ile iç geçerliği ve güvenirliği sağlanmıștır. Ayrıca, yazıya aktarılan ve- 
riler üzerinde araștırmacıların yaptığı çözümlemeler için nitel araștırma ve romatoloji alanında deneyimli iki akademisyenden görüș alınarak meslektaș yardımı olarak adlandııılan güvenirlik çalışması da gerçekleștirilmiştir.

\section{BULGULAR}

Araștırmaya katılan RA’lı hastaların sosyodemografik özellikleri Tablo 1'de verilmiștir.

Tablo 1: RA'ı hastaların sosyo-demografik ve hastalık özellikleri

\begin{tabular}{|c|c|c|}
\hline Özellikler & Sayı & $\%$ \\
\hline Yaș (ortalama) & \multicolumn{2}{|c|}{$48.54(30-71)$} \\
\hline $\begin{array}{l}\text { Cinsiyet } \\
\text { Kadın } \\
\text { Erkek }\end{array}$ & $\begin{array}{c}16 \\
8\end{array}$ & $\begin{array}{l}66.7 \\
33.3\end{array}$ \\
\hline $\begin{array}{l}\text { Eğitim durumu } \\
\text { Illköğretim ve altı } \\
\text { Ortaöğgretim }\end{array}$ & $\begin{array}{c}19 \\
5\end{array}$ & $\begin{array}{l}79.1 \\
20.9\end{array}$ \\
\hline $\begin{array}{l}\text { Medeni durum } \\
\text { Evli } \\
\text { Bekar }\end{array}$ & $\begin{array}{c}20 \\
4\end{array}$ & $\begin{array}{l}83.3 \\
16.7\end{array}$ \\
\hline
\end{tabular}

Çalıșma durumu

Callșiyor

Çalıșmıyor

Ev hanımı

Gelir durumu

Gelir giderden az

Gelir gidere eșit

Gelir giderden fazla

Yerleșim yeri

il

ilçe

Köy/kasaba

\begin{tabular}{|l|c|c|}
\hline Sigara kullanma durumu & \\
Evet & 7 & 29.2 \\
Hayır & 17 & 70.8 \\
\hline
\end{tabular}

\begin{tabular}{|l|c|c|}
\hline Alkol kullanma durumu & & \\
Evet & 1 & 4.2 \\
Hayır & 23 & 95.8 \\
\hline
\end{tabular}

\begin{tabular}{|c|c|c|}
\hline $\begin{array}{l}\text { RA hastalık yılı } \\
1-5 \text { yıl arası } \\
6-10 \text { yıl arası } \\
11-15 \text { yıl arası } \\
16 \text { yıl ve üzeri }\end{array}$ & $\begin{array}{l}7 \\
8 \\
1 \\
8\end{array}$ & $\begin{array}{r}29.2 \\
33.3 \\
4.2 \\
33.3\end{array}$ \\
\hline $\begin{array}{l}\text { Ailede RA hastalığı varlığı } \\
\text { Evet } \\
\text { Hayır }\end{array}$ & $\begin{array}{l}6 \\
8\end{array}$ & $\begin{array}{l}25.0 \\
75.0\end{array}$ \\
\hline $\begin{array}{l}\text { Deformasyon gelișme durumu } \\
\text { Evet } \\
\text { Hayır }\end{array}$ & $\begin{array}{l}14 \\
10\end{array}$ & $\begin{array}{l}58.3 \\
41.7\end{array}$ \\
\hline $\begin{array}{l}\text { Esslik eden hastalık varlığı } \\
\text { Evet } \\
\text { Hayır }\end{array}$ & $\begin{array}{l}10 \\
14\end{array}$ & $\begin{array}{l}41.7 \\
58.3\end{array}$ \\
\hline $\begin{array}{l}\text { ilaçlarını düzenli kullanma durumu } \\
\text { Evet } \\
\text { Hayır }\end{array}$ & $\begin{array}{c}23 \\
1\end{array}$ & $\begin{array}{r}95.8 \\
4.2\end{array}$ \\
\hline $\begin{array}{l}\text { Kontrollere düzenli gelme durumu } \\
\text { Evet } \\
\text { Hayır }\end{array}$ & $\begin{array}{c}23 \\
1\end{array}$ & $\begin{array}{c}95.8 \\
4.2\end{array}$ \\
\hline Toplam & 24 & 100.0 \\
\hline
\end{tabular}

RA'lı hastalarla yapılan bireysel görüșmeler sonucunda "tanıya verilen ilk tepki", "RA semptomlarının hastalar üzerindeki etkisi" ve "baş etme stratejileri" olmak üzere 3 tema ve 8 alt tema belirlenmiștir. Görüșmelerden elde edilen tema ve alt temalar Tablo 2'de verilmiștir.

\begin{tabular}{|c|l|l|}
\hline \multicolumn{2}{|c|}{ Tablo 2: Görrişmelerden elde edflen tema ve alt temalar } \\
\hline \multirow{2}{*}{ Kategori } & \multicolumn{1}{|c|}{ Temalar } & \multicolumn{1}{c|}{ Alt Temalar } \\
\hline \multirow{3}{*}{ Yașam Deneyimi } & Tanıya verilen ilk tepki & \\
\cline { 2 - 3 } & $\begin{array}{l}\text { RA semptomlarının hastalar } \\
\text { üzerindeki etkisi }\end{array}$ & $\begin{array}{l}\text { Fiziksel etkiler } \\
\text { Duygusal ve emosyonel etkiler } \\
\text { Sosyal etkiler } \\
\text { Ekonomik etkiler }\end{array}$ \\
\cline { 2 - 3 } & \multirow{2}{*}{ Baş etme stratejileri } & $\begin{array}{l}\text { Tedaviye uyum ve düzenli takip } \\
\text { Aile desteği } \\
\text { Öz-yönetim } \\
\text { Dine yönelim }\end{array}$ \\
\hline
\end{tabular}

\section{Tema 1: Tanıya verilen ilk tepki}

Araștırmaya katılan RA'ı hastaların bir kısmı tanı ilk konulduğunda çok üzüldüklerini, ilaçlardan korktuklarını, şok geçirdiklerini, inkâr etmeye çalıștıklarını, neden ben diye? sürekli sorguladıklarını ve ilaçlarını içmediklerini; bir kısmı ise aile ve akrabalarında RA'lı hasta olduğu için zorlanmadan kabullendiklerini ifade etmișlerdir. Yapılan açıklamalardan bazıları așağıdaki gibidir:

- Hastalığı ilk duyduğumda inkâr ettim. Öfkelendim ve ilaçlarımı içmedim. Ama sonrası daha kötüymüș. Öfkem beni iyileștirmedi $(30 y, K)$.

- Ailedeki birçok kişide olduğu için beklenen bir hastalıktı. Kabullenmem zor olmadı (36y, E).

\section{Tema 2: RA semptomlarının hastalar üzerindeki etkisi}

RA semptomlarının hastalar üzerindeki etkisi teması 4 alt tema altında incelenmiștir. Bunlar "fiziksel etkiler", "duygusal ve emosyonel etkiler", "sosyal etkiler" ve "ekonomik etkiler" dir.

\section{Tema 2.1. Fiziksel etkiler}

Araștırmaya katılan RA'lı hastalar ağrı ve hareket kısıtlılı̆̆ı nedeniyle günlük aktivitelerini yerine getirmekte zorlandıklarını, eve, ișe ve çocuklarına yetemediklerini, ayağa kalkarken zorlandıklarını, bazılarının tekerlekli sandalyeye bağlı olduğunu ve bir bașkasının yardımına muhtaç hale geldiklerini ifade etmișlerdir.

- Hareket kısıtlılığı ve deformasyonlarım nedeniyle yürüyemiyor, oturamıyor, lavaboya dahi gidemiyorum. Bir bașkasına tamamen bağımlı ve muhtaç hale geldim $(61 y, E)$.

- Ayaklarım çok ağrıyor, yürümekte bile zorlanıyorum. Ömrümün sonuna kadar nasıl dayanacağım diye düşü- 
nüyorum $(40 y, E)$.

\section{Tema 2.2. Duygusal ve emosyonel etkiler}

Araștırmaya katılan RA'lı hastaların ilk başlarda depresyon, anksiyete ve öfke patlamaları yașadıkları, kendilerine olan güvenlerinin azaldığı, daha da hassaslaștıkları, kendini bitkin hissettikleri, sürekli hastalıklarını düşündükleri için huzursuz oldukları, yoğun stres yașadıkları ve yașama umutlarını yitirdikleri belirlenmiștir.

- Hastalıktan sonra sürekli sinirli birisi oldum. Eșimle sürekli kavga ediyoruz. Kendime bakmak istemiyorum, hayattan bıktım artık $(61 y, E)$.

- Bana bir șey olursa çocuklarıma ve bana kim bakar diye korkuyorum. Bunları düșünmekten çoğu zaman depresyona giriyorum $(38 y, K)$.

\section{Tema 2.3. Sosyal etkiler}

Araștırmaya katılan RA'ı hastaların ağrıları ve hareket kısıtılıkları nedeniyle sosyal aktivitelere katılamadıkları, misafir ağırlayamadıkları, bazılarının tamamen insanlardan kendilerini soyutladıkları ve diğer insanlar gibi doya doya gezemedikleri belirlenmiștir.

- Halı saha maçına gidemiyorum. Arkadaș çevresinden kendimi soyutladım (35y, E, 45y, E).

- Diğer insanlar gibi doya doya gezemedim. Farklı aktivitelerde bulunamadım. lçime kapanık bir insan olmaya bașladım. Kendimi küçümsedim. Șekil bozukluklarım yüzümden insan içine çıkmak istemedim (30y, K).

\section{Tema 2.4. Ekonomik etkiler}

Araştırmaya katılan RA'lı hastaların bir kısmı hastalık yüzünden iş kaybı yaşadıklarını ya da iş yerinden çıkaracaklar korkusu yașadığını, ağrıları nedeniyle daha az çalıșmak zorunda kaldıklarını; bir kısmı ise ekonomik olarak etkilenmediğini ailesinin destek olduğunu ya da eșinin maașıyla geçindiğini ifade etmiştir.

- Calıșamaz hale gelince fabrikadan çıkmak zorunda kaldım (49y, K).

- Bu hastalık çalıșmamı etkiledi, işyerinden çıkaracaklar diye korkuyorum (36y, E).

- Allaha șükür ekonomik anlamda etkilenmedim. Eșimin maașıyla geçiniyorum $(64 y, K)$.

\section{Tema 3: Baș etme stratejileri}

Araştırmaya katılan RA'lı hastaların baş etme stratejileri teması 4 alt tema altında incelenmiștir. Bunlar "tedaviye uyum ve düzenli takip", "aile desteği”, "öz-yönetim" ve "dine yönelim" dir.

\section{Tema 3.1. Tedaviye uyum ve düzenli takip}

Araștırmaya katılan RA'lı hastaların büyük çoğunluğunun hastalıkla başa çıkmak için ilaçlarını düzenli olarak aldıkları, yetmediği zaman ağrı kesicilerle atlattıkları, doktor randevularına riayet ettikleri belirlenmiștir.

- Tanıyı ilk aldığımda ilaçlarımı almadım. Ama her yerim tutuldu, yatalak gibi oldum. Inatlașmaktan vazgeçtim. Sonra Romatoloğun verdiği ilaçları kullanmaya bașlayarak kendimi daha iyi hissetmeye bașladım. Ağrılarım azalmaya bașladı. (30y, K).

- Her gün ilaç alma düșüncesi beni çok üzdü. Dozlarımı bile kaçırmaya çalışıım. Ama çok geçmeden vücudumdaki etkisini fark ettim. Daha sonra ilaçlarımı düzenli almaya bașladım. Ömür boyu kullanacağımı bilmek beni üzüyor, ama deformasyonları önlemek için bașka çarem yok (35y, E).

\section{Tema 3.2. Aile desteği}

Araștırmaya katılan RA'lı hastaların hastalık sürecinde ailelerinin desteği ile hastalıkla bașa çıkmaya çalıștıklarını, ev işlerini yapamadıkları için aile üyelerinin bu işleri yerine getirdiğini, çocuklarının maddi ve manevi her konuda destek oldukları için rahatladıklarını, aile üyelerinin hastalıkla ilgili çeșitli kaynaklardan bilgi edinerek kendilerine yardımcı olmaya çalıștıklarını belirtmiștir.

- Bazen eklemlerim o kadar sertleșiyor ki hiçbir ev iși yapamıyorum. Böyle bir durumda eșim ve çocuklarım evde yemek yapmaktan temizliğe kadar tüm günlük işleri șikâyet etmeden yapıyorlar (46y, K).

- Eșim hastalık ilk tanı konduğu andan itibaren çok destek oldu ve beni teselli etti. Olumlu düsünmeme yardımcı oldu. Essim ve çocuklarım depresyona girmeme izin vermedi $(57 y, E)$.

\section{Tema 3.3. Öz-yönetim}

Araștırmaya katılan RA'lı hastaların bir kısmı hastalığın remisyon zamanlarında günlük aktivitelerini kendi bașlarına yerine getirmeyi çalıștıklarını, ev işleri yaparken küçük molalar verdiklerini, giyinme konusunda düğmelerin olmadı̆̆ı rahat giyip çıkarabilecekleri giysileri tercih ettiklerini, sabah tutukluklarını gidermek için ılık su torbaları koyduklarını, ağır eşya kaldırmaktan kaçındıklarını, bazı hastalar saçlarını kısa bir şekilde kestirdiklerini, eklem tutulumlarını azaltmak için spor yapmaya çalıștıklarını ve hastalık ile ilgili çeșitli kaynaklardan araștırma yaparak bilgilendiklerini belirtmișlerdir.

- ilk zamanlarda başa çıkmakta çok zorlandım. Ama sonra farkettim ki sadece ben değil, benim gibi bir sürü insan olduğunu gördüm. Bu bana hastalı̆̆ımla ilgili biraz da olsa öz güven verdi. Hastalı̆̆ımla ilgili sürekli 
internetten bir șeyler araștırdım. Sağglı programlarını seyrettim. Bu sayede hastalığımı nasıl yönetmem gerektiğini ögrendim (30y, K).

- Saçlarım çok uzundu. Ancak ellerimde tutulumlar olmaya bașlayınca kısa kestirmek zorunda kaldım. Ama iyi oldu, bu sayede rahat ettim (52y, K).

\section{Tema 3.4. Dine yönelim}

Araștırmaya katılan RA'lı hastaların büyük çoğunluğu sürekli Allaha dua ettiklerini, tutulumu olan hastaların sandalyede de olsa namaz kılmaya devam ettiklerini ve Kuran okuduklarını belirtmișlerdir.

- Allaha düzenli olarak dua ediyorum. Hastalığım sadece eklemlerimi etkilediği, organlarımı etkilemediği için Allaha șükrettim (60y, K).

- Oturarak da olsa Allah'ima çok dua ediyorum kimseye muhtaç etme. Daha kötü olmayayım diye (71y, K).

TARTIŞMA

Bu kalitatif çalıșma, RA ile yaşamanın hastaların yașamlarını tanı konduğu andan itibaren nasıl etkilediğini ve hastaIıkla nasıl baş ettiklerini ortaya koymak amacıyla yapılmıştır. Çalıșmadan "tanıya verilen ilk tepki", "RA semptomlarının hastalar üzerindeki etkisi (fiziksel etkiler, duygusal ve emosyonel etkiler, sosyal etkiler, ekonomik etkiler)" ve "baș etme stratejileri (tedaviye uyum ve düzenli takip, aile desteği, öz-yönetim, dine yönelim)" olmak üzere 3 tema ve 8 alt tema belirlenmiştir.

Tanıya verilen ilk tepki

Hastalığın ani bir şekilde ya da yavaş başlaması, belirti süreci bireyin hastalığa vereceği tepkisini etkileyebilmektedir. Hastalık sakatlığa neden olduysa, bireylerin günlük yaşam aktivitelerini yerine getirmesine engel oluyorsa ve yașamı tehdit eden bir hastalıksa ciddi stres yaratır. Fiziksel hastalığı olan hastaların tanı konduktan sonra hastalık sürecinde inanamama ve inkâr, irritabilite ve öfke, kontrolü kazanma girişimi, depresyon, kabul ve iş birliği yaşadıkları ifade edilmektedir (9). Kostava ve ark. (2014) İsviçre'de RA hastaları üzerinde yaptıkları nitel araștırmada, hastaların RA tanısı almayı bir ceza ve adaletsizlik olarak algıladıklarını, șok yaşadıklarını ve hastalığın nedenine mantıklı bir açıklama bulamadıklarını ifade etmișlerdir (10). LaChapelle ve ark (2008) çalıșmasında ise hastalar eski yaşam tarzlarını bırakıp yenisini benimsemek zorunda kaldıklarında yas duygularını dile getirmișlerdir (11). Hindistan'da 9 RA'lı kadınla yapılan çalıșmada, hastaların hastalığı ilk öğrendiklerinde inkâr ettikleri, üzüldükleri, ağladıkları, öncelikli olarak ilaç dışı yöntemleri kullandıkları ancak durumları kötüleșince Romatoloğa gidip ilaçlarını kullanmaya bașladıkları, bir süre sonra da ağrıya alıștıkları ve bu hastalığın tam olarak tedavi edilemeyeceğini ve hayatlarını bu hastalıkla yașamaları gerektiğini kabul ettikleri belirlen- miștir (4). Çalıșma sonucumuz literatürle benzerlik göstermekte olup tanı konduktan sonra RA hastalarının hastalığı nasıl anlamlandırdığı, hastalığa nasıl bir tepki verdiklerinin tespit edilerek tedaviye ve hastalığa uyum göstermeleri için sağık profesyonelleri tarafından destek mekanizmalarının oluşturulması önerilebilir.

\section{RA semptomlarının hastalar üzerindeki etkisi}

Romatoid artrit, fiziksel, psikolojik ve sosyal ișlevi etkileyebilen uzun süreli inflamatuar bir hastalıktır (12). Literatür incelendiğinde RA hastalarının ağrı, tutukluk, hareket kısıtlılı̆ı, yorgunluk, eklem deformitesi ve uyku bozukluğu gibi fiziksel problemler yaşadıkları, bu problemler nedeniyle de günlük yașam aktivitelerini yerine getirmekte zorlandıkları belirlenmiștir $(4,6,10,12-14)$. RA'lı hastalardaki bu fiziksel değișimler nedeniyle yașam kalitesi önemli ölçüde azalmakta ve anksiyete, depresyon, ajitasyon, öfke, ağlamaklı olma, sosyal geri çekilme gibi duygu durum değișikliklerine neden olmaktadır $(4,6,9,12,13)$. Genel popülasyonla karșılaștırıldığında, RA'lı bireylerde hem fiziksel engellilik hem de psikiyatrik komorbidite prevalansının arttı̆̆ ifade edilmektedir (15). Bu fiziksel ve psikolojik sorunlar RA'lı hastaların egzersiz yapamamasına, daha az sosyal olmasına ve daha izole olmasına neden olur. Ayrıca RA hastalarında semptomların öngörülemezliği, sabit bir bașlangıç zamanı olan mesleklerde kalmayı zorlaștırabilir. Sürekli ağrı, yorgunluk, fonksiyonel yetersizlik veya yüksek düzeyde hastalık aktivitesi olan hastalar sıklıkla ișten ayrılmak zorunda kalarak ekonomik problemler yașayabilir (7, 12). Çalıșmamızda da benzer problemler tespit edilmiş olup RA'lı bireylerin sadece fiziksel problemlerinin çözümlenmesine değil psikolojik, sosyal ve ekonomik olarak yașadıkları problemlere yönelik olarak da multidisipliner bir yaklaşımla tedavi programı olușturulmalı ve sosyal destek birimlerine yönlendirilmelidir.

\section{Baș Etme Stratejileri}

RA gibi kronik bir hastalığa yakalanma olgusu, hastanın yeni koșullara uyum sağlamasını gerektiren kritik, stresli bir yașam olayı olarak kabul edilmektedir. Zor durumlarla bașa çıkmak, stres ve mental sağlık arasında bir arabulucu görevi görür. Bu nedenle stresin etkilerinin șiddetlenip șiddetlenmeyeceği, başa çıkmanın etkinliğine bağııdır (16).

İlaç uyumu, hastalara ilaçların reçete edilmesi, ilaçlarına ne zaman bașlayacağı, ne kadar süre kullanmaya devam edeceği ve ne zaman ilaç kullanmayı sonlandıracağına ilișkin süreçlerin tümünü ifade eden bir terim olarak tanımlanmaktadır (17). RA'nın birden fazla organı etkilemesi, eklemlerde gelișen deformasyonlar sonucu fiziksel, psikolojik ve sosyal açıdan hayatlarını olumsuz etkileneceğinden RA hastaları için ilaç tedavisi vazgeçilmez olmaktadır $(18,19)$. Yapılmış çaIıșmalarda da RA hastalarının baș etme stratejileri arasında tedaviye uyum ve düzenli takip gelmektedir $(4,10)$. 
Baş etme stratejileri arasında yer alan durumlardan biri de sosyal destektir. Aile ve arkadaşlardan gelen destek, RA hastalarının sağlıklı kalmalarını ve hasta olduklarında daha hızlı iyileșmelerini kolaylaștırmaktadır (20). Literatürde aile üyelerinden ve arkadaşlardan elde edilen duygusal desteğin, kısıtlamalar ve ağrılı semptomlarla baș etmede ve evlerinde olumlu ortamı sürdürmede çok önemli olduğu, onlara umut duygusu verdiği, sosyal destek ile baș etme stratejileri arasında pozitif bir korelasyon olduğu belirtilmektedir $(4,20)$.

Çalıșmada RA hastalarının belirttiği baş etme yöntemlerinden birisi de öz-yönetimdi. Ağrının kendi kendine yönetimi, hastalık eğitimi ve aktivite ile dinlenme arasındaki denge, hastalara yaşamları üzerinde kontrol hissi vermektedir. Hastalar, kısıtlamaları ve değerleri arasındaki dengeyi sağlayarak beklentilerini gerçekçi bir șekilde yeniden yapılandırmaktadır (4). RA'lı hastalarda ağrı kabulünü araştıran nitel araștırmalarda, ağrının kronikliğini fark etmenin ve yașam hedeflerini yeniden tanımlamanın, RA'lı hastaların yașamlarında bir dönüm noktası olduğu ve bu sayede kendilerinde iyileșmeye yol açtı̆̆ bildirilmektedir $(4,10,11)$.

Maneviyat, ruh sağlığı açısından önemli bir değișkendir. Bireyler maneviyatı, kronik ağrı ile yașamanın zorlukları da dahil olmak üzere sıkıntılı durumlarla bașa çıkmanın bir yolu olarak kullanmaktadır (21). Derin dini inancı ve manevi deneyimleri olan RA hastalarında depresyonun daha az görüldügü, hastalığın olumlu unsurlarına katıldıkları, yașam hedefleri konusunda daha yüksek psikolojik esneklik gösterdikleri ve kronik hastalığa daha iyi uyum sağladıkları ifade edilmektedir (4, 21). Çalıșma bulguları literatürle benzerlik göstermektedir.

\section{Araștırmanın Sınırlılıkları}

Çalıșma, nitel araștırma tekniği ile yapılması nedeniyle elde edilen bulgular sadece araștırmaya katılan 24 RA'lı bireyin görüşü ile sınırlı olup, genellenemez.

\section{SONUÇ}

Sonuç olarak, RA'lı hastaların tanı konduğu anda inkâr, öfke ve kızgınlık yaşadıkları, ama hastalık süreci ve ailede de aynı hastalığın bulunması nedeniyle kabullendikleri, RA nedeniyle fiziksel, duygusal/emosyonel, sosyal ve ekonomik olarak problemler yașadıkları, bu problemlerle baș etmek içinde ilaçlarını düzenli kullanma, doktor kontrollerine gitme, aileden destek alma, öz-yönetimlerini sağlama ve dini uygulamaları kullandıkları saptanmıștır. Bu çalışma, kronik hastalıkla yașamanın ve iyi bir yașam kalitesini sürdürmenin tek boyutlu bir sürecin sonucu olmadığını, psikolojik, sosyal ve ruhsal bileșenlerden oluşan çok boyutlu süreçler olduğunu göstermektedir. Bu çalıșmanın bulguları, sağlık profesyonellerinin hastalık yönetiminde hastanın bakış açısını dikkate alma ve holistik bir yaklașımla tedavilerini olușturmaları gerekliliğine vurgu yapmaktadır. RA hastalarına hastalık semptomları ile baș etmeleri için ilaçlarını düzenli olarak kullanmaları ve sağlık kontrollerine düzenli gelmeleri konusunda eğitim verilmesi, ruhsal sorunları tespit edilen hastaların psikolojik destek birimlerine yönlendirilmesi, stres ile baș etme yöntemlerinin ögrretilmesi ve olumlu baș etme yöntemleri kazandırmak için danışmanlık hizmeti sunulması önerilmektedir.

\section{BILDIRIMLER}

Değerlendirme

Dıș danıșmanlarca değerlendirilmiştir.

Çıkar Çatıșması

Yazarlar bu makale ile ilgili herhangi bir çıkar çatıșması

bildirmemişlerdir.

Finansal Destek

Yazarlar bu çalıșma sırasında herhangi bir finansal destek kullanmamıșlardır.

Etik Beyan

Bu çalışma için Burdur Mehmet Akif Ersoy Üniversitesi Girișimsel Olmayan Klinik Araștırmalar Etik Kurulundan 13.05.2020 tarih ve GO 2020/124 sayılı yazı ile izin alınmıș olup Helsinki Bildirgesi kriterleri göz önünde bulundurulmuștur.

\section{KAYNAKLAR}

1. Shaw Y, Bradley M, Zhang C, Dominique A, Michaud K, McDonald D, et al. Development of resilience among rheumatoid arthritis patients: a qualitative study. Arthritis Care Res. 2020;72(9):1257-1265. https://doi.org/10.1002/ acr.24024

2. Lin YJ, Anzaghe M, Schülke S. Update on the pathomechanism, diagnosis, and treatment options for rheumatoid arthritis. Cells. 2020;9(4):880. https://doi.org/10.3390/cells9040880

3. Monti S, Montecucco C, Bugatti S, Caporali R. Rheumatoid arthritis treatment: the earlier the better to prevent joint damage. RMD Open. 2015;1(Suppl 1):e000057. https://doi. org/10.1136/rmdopen-2015-000057

4. Chavare S, Natu S. Life of Indian women with rheumatoid arthritis: a qualitative study. IOSR Journal of Humanities and Social Science. 2020;25(3):1-12. https://doi.org/10.9790/08372503050112

5. Schneider M, Manabile E, Tikly M. Social aspects of living with rheumatoid arthritis: a qualitative descriptive study in Soweto, South Africa - a low resource context. Health Qual Life Outcomes. 2008;6(54):1-11. https://doi.org/10.1186/14777525-6-54

6. Aundhia C, Patel S, Shah N, Parmar G, Seth A. Psychological effects and management of rheumatoid arthritis. Int J Pharm Res. 2020;12(2):2033-2039. https://doi.org/10.31838/ ijpr/2020.12.02.273

7. Jain A, Aggarwal A, Adams J, Jordan JE, Sadhra S, Dubey S, et al. Work productivity loss among rheumatoid arthritis patients in India: a qualitative study. Rheumatol Adv Pract. 2019;3(2):rkz046. https://doi.org/10.1093/rap/rkz046 
8. Schwind JK, Fredericks S, Metersky K, Porzuczek VG. What can be learned from patient stories about living with the chronicity of heart illness? A narrative inquiry. Contemp Nurse. 2016;52(2-3):216-229. https://doi.org/10.1080/10376 178.2015 .1089179

9. Kocaman N. Hastaların psikososyal tepkilerini etkileyen faktörler. Atatürk Üniversitesi Hemșirelik Yüksekokulu Dergisi. 2008;11(1):101-112.

10. Kostava Z, Zufferey MC, Schulz PJ. The process of acceptance among rheumatoid arthritis patients in Switzerland: a qualitative study. Pain Res Manag. 2014;19(2):61-68. https:// doi.org/10.1155/2014/168472

11. LaChapelle LD, Lavoie S, Boudreau A. The meaning and process of pain acceptance. Perceptions of women living with arthritis and fibromyalgia. Pain Res Manag. 2008;13(3):201210. https://doi.org/10.1155/2008/258542

12. Ryan S. Psychological effects of living with rheumatoid arthritis. Nurs Stand. 2014;29(13):52-59. https://doi. org/10.7748/ns.29.13.52.e9484.

13. Akkaya F, Kıyak E. Evaluation of the loneliness, social support and quality of life in patients with rheumatoid arthritis. International Journal of Caring Sciences. 2018;11(1):457-463.

14. Baloğlu HH, Aşkın A, Yener M. Determination of the factors that affect health related quality of life in patients with rheumatoid arthritis. Acta Medica Mediterranea. 2015;31(3):687-695.

15. Sturgeon JA, Finan PH, Zautra AJ. Affective disturbance in rheumatoid arthritis: psychological and disease-related pathways. Nat Rev Rheumatol. 2016;12(9):532-542. https:// dx.doi.org/10.1038\%2Fnrrheum.2016.112
16. Janiszewska M, Baranska A, Kanecki K. Coping strategies observed in women with rheumatoid arthritis. Ann Agric Environ Med. 2020;27(3):401-406. https://doi.org/10.26444/ aaem/110958

17. Ruppar TM, Dobbels F, Lewek P, Matyjaszczyk M, Siebens K, Geest SM. Systematic review of clinical practice guidelines for the improvement of medication adherence. Int J Behav Med. 2015;22:699-708. https://doi.org/10.1007/s12529-015-9479-x

18. Kim D, Choi JY, Cho SK, Choi CB, Bang SY, Cha HS, et al. Prevalence and associated factors for non-adherence in patients with rheumatoid arthritis. J Rheum Dis. 2018;25(1):47-57. https:// doi.org/10.4078/jrd.2018.25.1.47

19. Bharthi P, Shobha V, Subramanya A. atterns of drug use and factors affecting adherence to medication in patients with rheumatoid arthritis: A prospective, observational, hospitalbased study. Internet Journal of Rheumatology and Clinical Immunology. 2019;7(1):1-9. https://doi.org/10.15305/ijrci/ $v 7 i 1 / 316$

20. Arshad H, Kazmi UER. Social support and coping strategies among rheumatoid arthritis patients. Pakistan J Soc Clin Psychol. 2013;11(2):7-13.

21. Pourshahbazi M, Imani M, Sarafraz MR. Relationship between spirituality components with valued life in women with rheumatoid arthritis. J Res Relig Health. 2019;5(2):89-100. https://doi.org/10.22037/jrrh.v5i2.19017. 